\title{
Assessment of nutritional requirement of wheat variety KT-2000 under rainfed condition
}

\author{
Muhammad Ilyas ${ }^{1}$, Zahid Iqbal ${ }^{1}$, Sabir Gul Khattak ${ }^{1}$, Fahim Ullah \\ Khan $^{1,2^{*}}$, Zahid Saleem ${ }^{1}$, Muhammad Khan ${ }^{1}$, Javed Iqbal ${ }^{1}$ and Niaz \\ Muhammad $^{1}$ \\ 1. Barani Agricultural Research Station Kohat, KPK, Pakistan \\ 2. Department of Plant Breeding \& Genetics, The University of Agriculture, Peshawar \\ *Corresponding author's email: $\underline{\text { fahimbiotech@gmail.com }}$
}

\section{Citation}

Muhammad Ilyas, Zahid Iqbal, Sabir Gul Khattak, Fahim Ullah Khan, Zahid Saleem, Muhammad Khan, Javed Iqbal and Niaz Muhammad. Assessment of nutritional requirement of wheat variety KT-2000 under rainfed condition. Pure and Applied Biology. Vol. 4, Issue 4, 2015, pp 497-502. http://dx.doi.org/10.19045/bspab.2015.44007

Received: 07/06/2015

Revised: $05 / 11 / 2015$

Accepted: 14/11/2015

\section{Abstract}

As increasing fertilizer use efficiency would be beneficial to low value crop producer and friendly environment, a field experiment was thus conducted to assess the nutritional requirements of wheat variety KT-2000 at Barani Agricultural Research Station (BARS), Kohat during 2011-12 crop season. Wheat variety KT-2000 was planted in field condition under varied combination of NPK using randomized complete block (RCB) design with three replications. Data were recorded on days to heading, maturity, plant height, productive tillers $\mathrm{m}^{-2}$ and grain yield. Analysis of variance showed significant effect of NPK treatments on all the traits studied except plant height. Maximum values for economically important traits viz. productive tillers $\mathrm{m}^{-2}$ and grain yield were observed at maximum level of NPK (90-60-60). Regression analysis for all the traits confirmed the linear relationship of NPK fertilization with yield and yield associated traits. The highest grain yield of $3800 \mathrm{~kg} \mathrm{ha}^{-1}$ was recorded by applying NPK @ 90-60-60 kg ha-1 followed by 3767 and $3600 \mathrm{~kg} \mathrm{ha}^{-1}$ obtained by applying NPK @ 60-60-30 and 60-30-0 kg ha-1 respectively. Therefore, NPK @ 90-60-60 could be recommended for wheat variety KT-2000 to obtain high grain yield.

Keywords: Fertilizer application; NPK; Wheat; Grain yield.

\section{Introduction}

Nitrogen comprises $7 \%$ of total dry matter of plants and is a constituent of many fundamental cell components such as nucleic acids, amino acids, enzymes, and photosynthetic pigments [1].

Nutrients are lost from the soil plant system in a number of ways including, leaching, volatilization, de-nitrification, precipitation and fixation by clay minerals. Considerable amount of nutrients are taken up from the soil in harvested crop material. For sustainable agriculture, fertility of the soil must be maintained by adding fertilizers to the soil both in natural and organic form. So it is therefore, imperative to add fertilizers to the soil either in organic or in mineral form to get maximum yield of the crops. The 
types and amounts of fertilizer to be applied depend on the crop to be grown and nutrient supplying power of soil. It has been reported that judicious and balanced fertilizer can increase crop yield up to 40-50\% [2].

A nutrient imbalance exists when one or more nutrients are not in applied in proper ratio. This can cause deficiency, toxic level of one or more nutrients or just excess of a nutrient that is not toxic but hinders another nutrient from performing its normal function. A constant and balanced supply of elements is essential to good plant growth, otherwise nutrient deficiencies, toxicities or other effect, will cause plant nutrients stress. So soil analysis is a better diagnostic tool than other methods of fertility evaluation because it gives rapid results before sowing of crop. By knowing the actual status of the soil and application of balanced fertilizers, the maximum and economical crop production can be obtained as well as fertility of the soil could be restored [3]. The present experiment was designed to determine the optimum levels of NPK for achieving the profitable yield of improved variety (KT-2000) under the agro-climatic conditions of Kohat.

\section{Materials and Methods \\ Soil analysis:}

The physio-chemical analysis of composite soil sample indicated that the experimental site had $\mathrm{pH}$ value of 7.61 with electrical conductivity of $0.18 \mathrm{~d} \mathrm{~S} / \mathrm{m}$. Soil was alkaline, strongly calcareous $\left(20 \% \mathrm{CaCO}_{3}\right)$, deficient in organic matter, nitrogen and phosphorus and adequate in potassium. It has no problem of salinity and is clay loam in texture (Table 1).

Table 1. Physico-chemical characteristics of experimental site at BARS, Kohat.

\begin{tabular}{|l|l|l|}
\hline \multicolumn{1}{|c|}{ Parameter } & \multicolumn{1}{c|}{ Unit } & \multicolumn{1}{c|}{ Value } \\
\hline $\mathrm{pH}$ & - & 7.61 \\
\hline $\mathrm{EC} 10^{3}$ & $\mathrm{ds} / \mathrm{m}$ & 0.18 \\
\hline $\mathrm{CaCO} 3$ & $\%$ & 20 \\
\hline Organic Matter & $\%$ & 0.8625 \\
\hline Nitrogen & $\%$ & 0.0431 \\
\hline Phosphorus & $\mathrm{mg} / \mathrm{kg}$ & 9.78 \\
\hline Potash & $\mathrm{mg} / \mathrm{kg}$ & 104.5 \\
\hline Clay & $\%$ & 42 \\
\hline Silt & $\%$ & 38 \\
\hline Sand & $\%$ & 20 \\
\hline Textural Class & - & Clay loam \\
\hline
\end{tabular}

Yield and Yield Component: Days to heading (days)

Analysis of variance regarding days to heading as affected by different combination of NPK depicted highly significant differences among treatments (Table 2). Days to heading were ranged from 120 to 124 days with the average value of 122 days. Mean values indicated that days to heading was delayed in plots received maximum dose of NPK (T5= 90-60-60 kg $\mathrm{ha}^{-1}$ ), which was statistically similar with that of T4 and T3. On the other hand earliest heading was observed in plots received NPK @ 30-30-0. These results suggested that increase in NPK application delayed heading period in wheat (Table 3). Regression analysis showed linear relationship of five treatments with days to heading. $\mathrm{R}^{2}$ value $(0.75)$ approaches to 1 indicating the significance and the fitness of the linear model (Fig 1). The present results 
are in accordance with the earlier finding of $[2,3,4]$

Days to maturity (days)

Days to maturity varied significantly by different combination of NPK treatments (Table 2). Mean days to maturity ranged from 158 to 168 days with the average value of 163 days over all the treatments. Earliest maturity was observed in plots where NPK was not applied $(\mathrm{T} 1=0-0-0)$. On the other hand maturity was delayed in plots received maximum dose of NPK @ 90-60-60. NPK application keeps the plant canopy green and delayed plant senescence (Table 3). Linear trend of five treatments with days to maturity was observed with $\mathrm{R}^{2}$ value (0.99) indicated the significance and the fitness of the linear model (Fig 2). Earlier studies of $[4,5]$ reported similar results regarding days to maturity in wheat.

Table 2. Mean square for various morpho-physiological and yield traits of wheat variety KT-2000 as affected by different NPK combination.

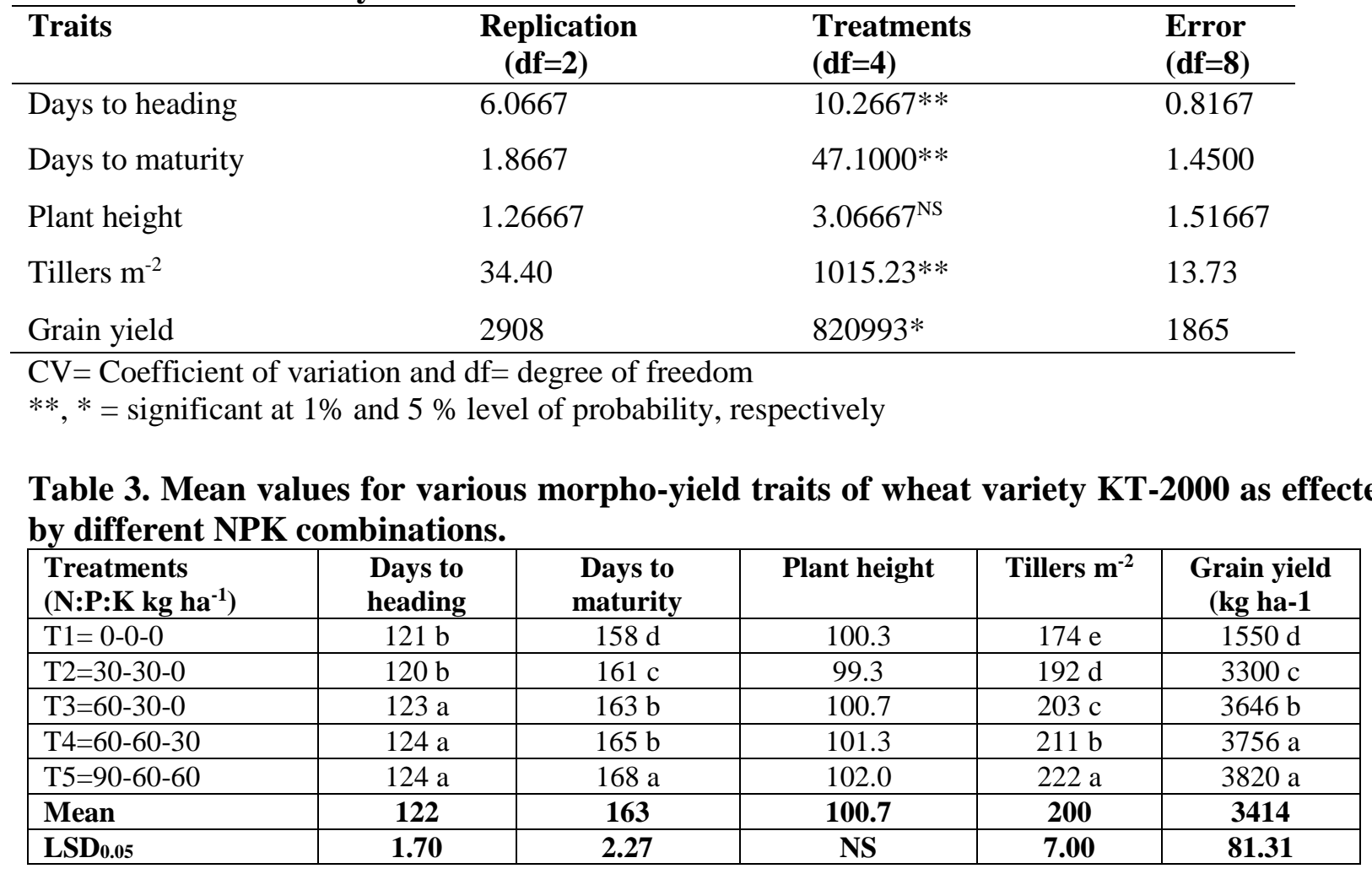

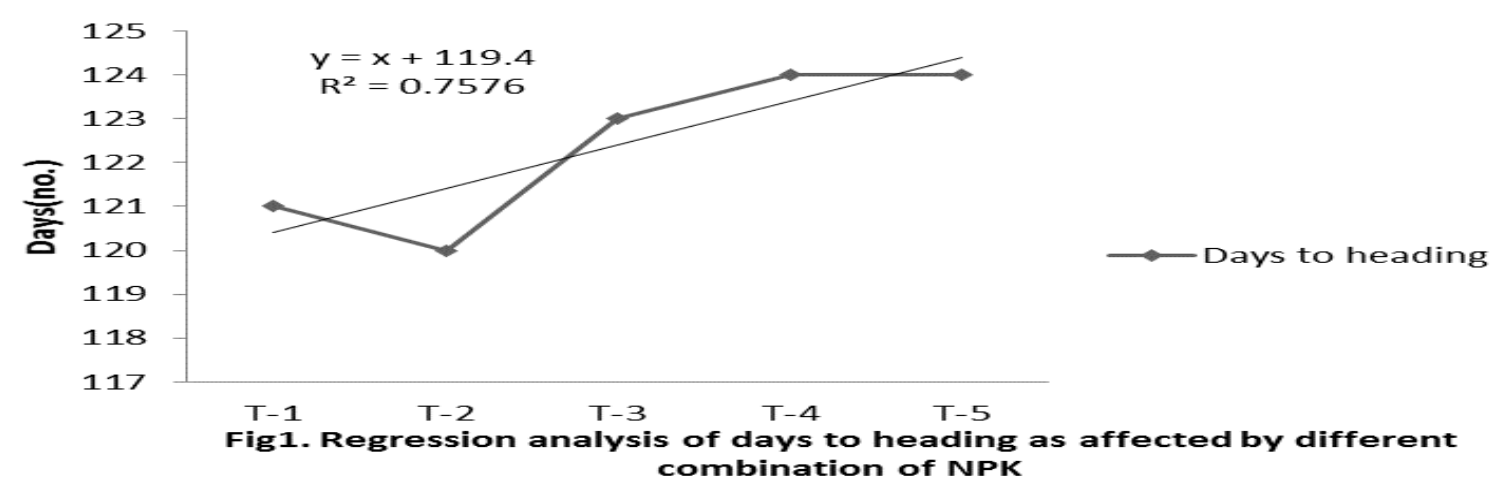


Plant height (cm)

Mean square regarding plant height showed non-significant differences among treatments (Table 2). Non-significant differences among treatments indicates that effect of NPK doses had no influence on height of the plant. Plant height ranged from 99.3 to $102.0 \mathrm{~cm}$ with the mean value of 100.7. Although different combination of NPK did not affect plant height of wheat variety KT-2000, however maximum and minimum plant height were recorded at $\mathrm{T} 3$ $(100.7 \mathrm{~cm})$ and T2 $(99.2 \mathrm{~cm})$ (Table 3). As non-significant difference among treatments were recorded for plant height, data for regression analysis was not plotted. These findings are contrary to the earlier research work $[4,6,7]$, they found significant effect of NPK fertilization on plant height.
Productive tillers $\mathbf{m}^{-2}$

Analysis of variance for productive tillers $\mathrm{m}^{-}$ 2 depicted highly significant differences among NPK treatments (Table 2). Productive tillers $\mathrm{m}^{-2}$ ranged from 174 to 222 tillers with the mean value of 200 tillers $\mathrm{m}^{-2}$. Maximum productive tillers $\mathrm{m}^{-2}$ were recorded in plots receiving NPK @ 90-6060 (222), whereas, minimum productive tillers $\mathrm{m}^{-2}$ were recorded in T1 plots (174) (Table 3). Regression analysis for productive tiller $\mathrm{m}^{-2}$ showed linear relationship of tillers with NPK doses. Linear increase in tillers were observed with the increase in NPK levels. High $\mathrm{R}^{2}$ value (0.97) indicated the significance and fitness of the model (Fig 3). Similar results regarding tillers $\mathrm{m}^{-2}$ were also reported by $[4$,
8 ,

10 ,
11].
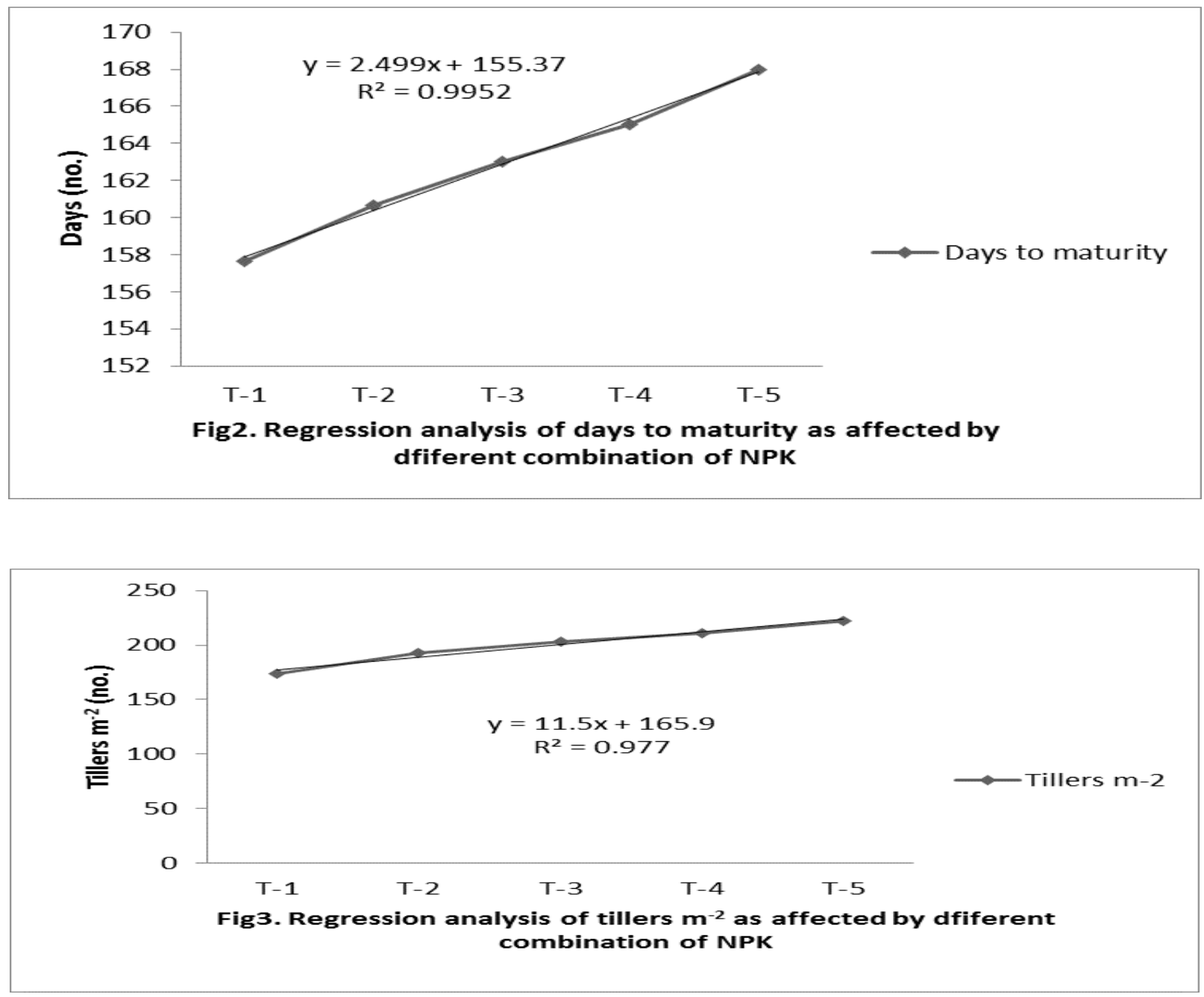


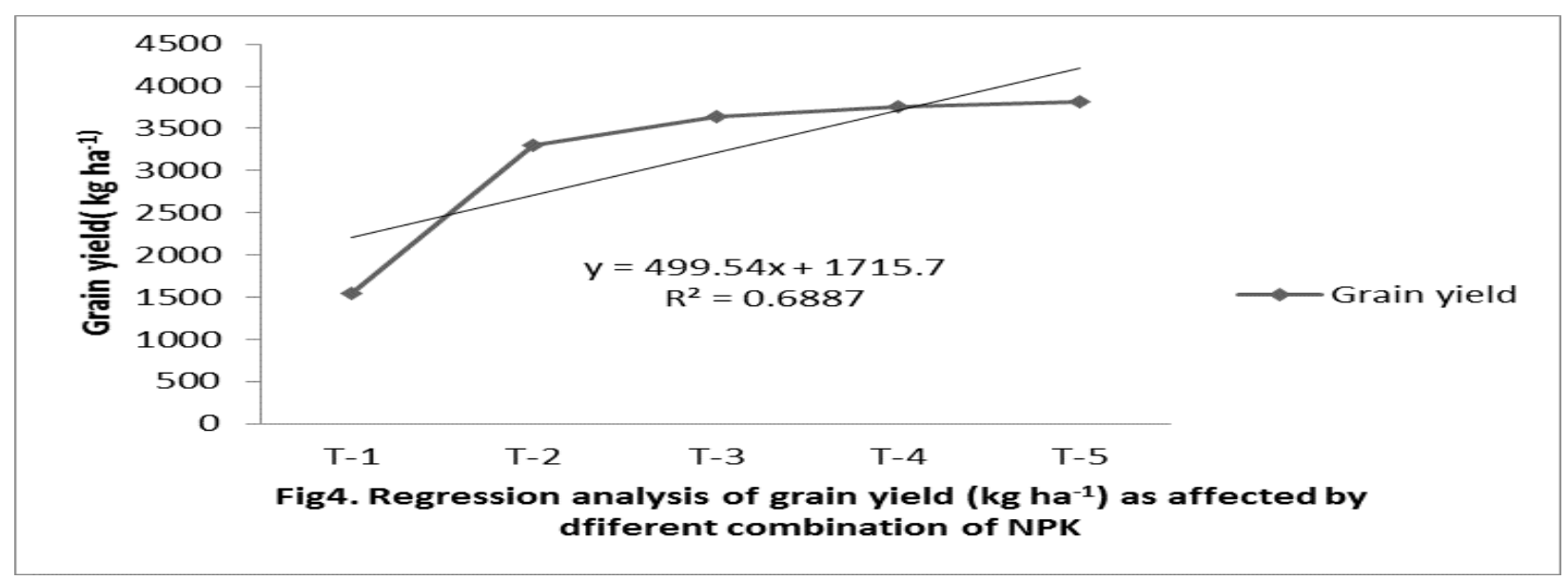

\section{Grain yield ( $\left.\mathrm{kg} \mathrm{ha}^{-1}\right)$}

Grain yield of wheat varieties was significantly affected by varied level of NPK (Table 2). Grain yield under varied level of nitrogen ranged from 1550 to $3820 \mathrm{~kg} \mathrm{ha}^{-1}$. Significant increase in grain yield with increase in NPK levels signify the importance of macro nutrients ( $\mathrm{N}, \mathrm{P}$ and $\mathrm{K}$ ) in crop growth. Maximum grain yield was observed in plots received NPK @ 90-60-60 (3820 kg ha-1), however it was statistically similar with plots receiving NPK @ 60-6030 (3756 kg ha $\left.{ }^{-1}\right)$. Minimum grain yield $\left(1550 \mathrm{~kg} \mathrm{ha}^{-1}\right)$ were recorded in plots received no NPK dose indicates there is sufficient amount mineral available to the crop to produce yield (Table 3 ). Regression analysis of grain yield data indicate linear relationship of NPK levels with grain yield. The $\mathrm{R}^{2}$ value of 0.68 indicates the fitness of the linear model of grain yield with NPK doses (Fig 4). Role of NPK in grain yield have been previously reported by many researcher. The present research work are in accordance with the earlier findings of [9, 10, 11]. They found highest wheat grain and straw yield with NPK @ 120-90-60 kg ha-1 respectively. Increased grain yield with increase in nitrogen level were also reported by [6]. Similarly, [12] also reported linear relationship of grain yield with the increase in NPK fertilization.

\section{Authors' contributions}

Conceived and designed the experiments:

SG Khattak. Performed the experiments: M Ilyas \& Z Iqbal. Analyzed the data: F Khan \& Z Saleem. Contributed reagents/materials/analysis tools: J Iqbal \& N Muhammad. Wrote the paper: F Khan \& M Khan.

\section{References}

1. Bungard RA, Wingler A, Morton JD \& Andrews M (1999). Ammonium can stimulate nitrate and nitrite reductase in the absence of nitrate in Clematis vital. Plant Cell Env 22: 859-866.

2. Memon KS (1996). Soil and fertilizer phosphorus. In Soil Science- National Book Foundation, Islamabad. 291-314.

3. Bhatti A, Qureshi AA \& Rahman S (1985). Effect of $\mathrm{N}$ alone in combination with $\mathrm{P} \times \mathrm{K}$ on the yield of wheat. Pakistan J. Agric. Res. 6 (2): 89-92.

4. Khan I, Mohammad F \& Khan FU (2015). Estimation of genetic parameters of yield and yield related traits in wheat genotypes under rainfed conditions. Int'l J Environ 4(2): 193-205.

5. Ayoub M, Guertin S, Lussier S \& Smith DL (1994). Timing and levels of nitrogen 
fertility effects on spring wheat. Crop Sci 34: 748-750.

6. Geleto $\mathrm{T}$, Tanner DG, Mamo $\mathrm{T} \&$ Gebeyehu G (1995). Response of rain fed bread and durum wheat to source level and timing of nitrogen fertilizer on two Ethiopian vertisole S. I. yield and yield components. Comm in Soil Sci Plant Analysis 26: 1773-1794.

7. Jan S, Mohammad F \& Khan FU (2015). Genetic potential and heritability estimates of yield traits F3 segregating populations of bread wheat. Int'l $J$ Environ 4(2): 106-115.

8. Singh VPN \& Uttam SK (1992). Response of wheat cultivars to different $\mathrm{N}$ levels under early sown conditions. Crop Res 5: 82-86.

9. Chaudhry GA, Nawaz S, Hussain R, Asghar A \& Kashif SR (2000). Fertilizer requirements of new wheat genotype under rain fed condition. Pakistan J Soil Sci 18: 125-109.

10. Khan FU, Raziuddin \& Khalil IA (2013). Correlation and factorwise contribution of various traits related to yield in rapeseed (Brassica napus L.). American-Eurasian J Agric \& Environ Sci 13 (1): 101-104.

11. Khan FU, Khan M, Khattak SG, Iqbal Z, Saleem Z, Iqbal J \& Muhammad N. Evaluation of advance bread wheat lines in preliminary wheat yield trial. Pure Appl Bio 4(3): 384-388.

12. Lathwal OP, Tej S \& Singh T (1992). Effect of irrigation and nitrogen levels on yield attributes and yield of wheat. Haryana $J$ Agron 8: 69-70. 